International Journal of Instruction

e-ISSN: 1308-1470 • www.e-iji.net

Article submission code:

20210120205749

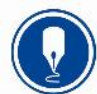

January $2022 \bullet$ Vol.15, No.1

p-ISSN: 1694-609X

pp. $765-780$

Received: 20/01/2021

Revision: 05/08/2021
Accepted: 30/08/2021

OnlineFirst: $14 / 11 / 2021$

\title{
Lecture, Cooperative Learning and Concept Mapping: Any Differences on Critical and Creative Thinking Development?
}

\section{Helena Silva}

University of Trás-os-Montes e Alto Douro / CIIE (Centre for Research and Intervention in Education), University of Porto, Portugal, helsilva@ utad.pt

\section{José Lopes}

Dr., University of Trás-os-Montes e Alto Douro / CIIE (Centre for Research and Intervention in Education), University of Porto, Portugal, jlopes@utad.pt

\section{Caroline Dominguez}

University of Trás-os-Montes e Alto Douro / LabCTD-CIDTFF (Research Centre on Didactics and Technology in the Education of Trainers) University of Aveiro, Portugal, carold@utad.pt

\section{Eva Morais}

University of Trás-os-Montes e Alto Douro / CMAT (Centre of Mathematics) University of Minho, Portugal, emorais@utad.pt

This study investigated the effects of lecturing, cooperative learning and concept maps on the development of critical and creative thinking skills. A quasiexperimental non-randomized study involved a class of students from the 3rd year of Psychology and two classes from the 3rd year of Pre-service Elementary Teachers. The study ran for 15 weeks, one semester. In one of the Primary School Teaching classes, cooperative learning and concept maps were used and in the other only cooperative learning. The Critical and Creative Thinking test was applied to assess pre and post critical and creative thinking skills. The results show that students from the two classes that used cooperative learning and cooperative learning + concept maps improved further critical and creative thinking skills in relation to the lecturing class, with no significant differences between the first two. Pedagogical recommendations are made according to these results.

Keywords: lecture, cooperative learning, concept mapping, critical and creative thinking skills, higher education

\section{INTRODUCTION}

Resulting from various initiatives and studies carried out by international academic and professional organizations (Council of Europe, 2016; OECD, 2018; UNESCO, 2016) which highlight the need for Higher Educational reforms in order to respond to the

Citation: Silva, H., Lopes, J., Dominguez, C., \& Morais, E. (2022). Lecture, cooperative learning and concept mapping: Any differences on critical and creative thinking development? International Journal of Instruction, 15(1), 765-780. https://doi.org/10.29333/iji.2022.15144a 
social and economic challenges of the 21 st century, a consensus has been met on the importance for students to develop Critical and Creative Thinking (CCT) skills in an explicit, consistent and ongoing way (Dominguez, 2018; Fullan et al., 2018; Lucas \& Spencer, 2017). CCT, among others so called soft skills, is supposed to get students equipped for their active and positive engagement in the ongoing transformations of society/professions towards technical, economic, social and environmentally sustainable goals. Higher Education Institutions (HEI) are thus compelled to prepare students to thinking todays' problems critically and creatively integrating multiple perspectives. Gradually, HEI are introducing across their curricula a variety of active pedagogic strategies which help enhance CCT (Bezanilla et al., 2019; Kusumoto, 2018), moving gradually away from the still predominant traditional lecture method of instruction (Schmidt et al., 2015). These are mostly based on the social constructivist learning theory (Vygotsky, 1978) that favours a learning process in which students' social and cultural interactions play a major role, putting emphasis on knowledge as a coconstruction and on individuals learning from one another, as they are engaged in the learning process.

In agreement with its generalized characterization and despite the many definitions of Critical Thinking (CT) in the literature (which tend to focus on more specific aspects) (Facione, 1990; Halpern \& Dunn, 2021; Norris \& Ennis, 1989; Sternberg, 1986), CT can be defined as a higher-order thinking skill (Bloom et al., 1956) which mobilizes cognitive functions like: debunking biases, analysis, explanation, interpretation, inference making, evaluation, argumentation, in depth questioning, meta cognition (detecting weaknesses in the way of thinking), decision making (what to believe or do), among others.

It is not uncommon to associate creativity, or creative thinking (CrT) to CT (Halpern \& Dunn, 2021; Bonk \& Smith, 1998; Paul \& Elder, 2019) since CT includes skills related to cognitive functions often linked to problem solving. Following Kaufman and Sternberg (2019) creativity can be defined as the ability to produce work that is both novel (i.e. original, unexpected) and appropriate (i.e. useful, adaptive concerning tasks constraints) in a certain context. Halpern and Dunn (2021) points out that a certain amount of creativity goes together with CT. She reinforces Paul and Elder's (2019) idea that CCT are two sides of the same coin, developing in parallel. Good thinking requires the ability to generate intellectual products, which is associated with creativity. However, good thinking requires also from the individuals that they are aware and critical about the quality of these intellectual products. As the authors note, "critical thinking without creativity is reduced to mere scepticism and negativity, and creativity without critical thinking is reduced to mere novelty" (Paul \& Elder, 2019, p. 35). Most authors agree with Torrance's (1970) characteristics of the CrT process. It includes fluency (having many relevant ideas), flexibility (having different types of relevant ideas), originality (having statistically novel ideas) and elaboration (being able to elaborate one's ideas). Often associated to imagination, to the ability to think outside the box, to generate ideas and to problem solving, it can be fostered at the individual level, but it is mostly linked to collaborative work and learning (Hämäläinen \& Vähäsantanen, 2011). 
Drawing from the more recent literature at the HEI level which pinpoints Cooperative Learning (CL) and Concept Mapping (CM) as being two effective pedagogic strategies which support CCT development (Bezanilla et al., 2019; Dominguez, 2018), this article has the objective to contribute, from an empirical point of view to the ongoing investigation. It brings up a quasi-experimental study with a pre and post CCT assessment test comparing 3 situations (lecture, CL alone, CL and CM). Its novelty lies in the fact that although there is abundant evidence that CL promotes cognitive development, there is, to our knowledge, fewer evidence on the potentiality of CL and the use of CM (Bixler et al., 2015; Schroeder et al., 2017), with pre and post-test CCT assessment (Silva et al., 2020). Thus, our main objective is to answer to the following questions: what is (are), among traditional lecturing, CL, and CL and concept maps, the most efficient strategy(ies) to promote CCT? Is the association of CM with CL an added value for the development of CCT? To what extent? Which dimensions of CCT skills are most promoted in each experiential situation? Which recommendations can be drawn at the practical level for teachers?

\section{Literature Review}

\section{Lecturing and Critical and Creative Thinking}

Lecturing is a method centered on the teacher, in which he/she organizes the contents in smaller parts to be more easily understood by the students. The teacher usually presents the content using slides (PowerPoint) including diverse information formats like text, videos, images, etc. (Sudarmika et al., 2020). In general, the presentation is followed by a question and answer session during a short period of time. Students usually play a more passive role limiting themselves to taking notes and listening (Canaleta et al., 2014). In this type of teaching, students generally do not have any other type of intervention in class with the teacher or colleagues. The interaction which may occur is when study groups are organized by the students. In this method, the teacher provides students with the correct answer in various contexts and students are supposed to use the knowledge in solving problems that require such responses (Spence, 2004). They are not encouraged to engage in higher-order thinking and they only focus on the content and in answering to comprehension questions. An expository class can, however, promote CT as long as it is planned to provoke a deep intellectual engagement, involving students in effective questioning processes (McKeachie \& Svinicki, 2014). It seems however that traditional lecturing still prevails in HE, limiting thus the preparation for students to be critical and creative thinkers (Al-Zahrani, 2015).

\section{Cooperative Learning and Critical and Creative Thinking}

Cooperative Learning (CL) is an active learning method centered in students (Johnson \& Johnson, 2014). In CL, students work in heterogeneous small groups to perform activities, share ideas and reach common learning objectives. Through their interaction, many opportunities emerge to present ideas, debate, defend or question arguments, evaluate and synthesize information coming up with a better understanding and a shared (and new) knowledge or solutions (Cottell \& Millis, 1992), enabling the promotion of CCT (Warsah et al., 2021). This is explained by the fact that the confrontation of ideas often leads to a cognitive and socio-cognitive conflict and to an epistemic unfreezing 
(Fransen et al., 2013; Morais et al., 2017) triggering students' curiosity and search for more knowledge, which in turn results in the questioning of their own beliefs and knowledge. That is, when students are faced with different and equally well-grounded perspectives, uncertainty about the correctness of their initial position increases, which translates into the search for more information and a more adequate perspective to explain the situation under analysis. When justifying their position or detecting weaknesses and strengths in the others' points of view, CL promotes CCT skills like analysis, evaluation, argumentation, etc. (Lopes \& Silva, 2009).

Among the cooperative methods, Think-Pair-Share (TPS) and Jigsaw are particularly relevant for CT promotion.

The TPS method (Lyman, 1987) is structured in three phases: (1) Think. The teacher forms heterogeneous groups of four students and sets out a subject to discuss or a problem to solve, giving students "time to think individually" in the answer: (2) Form pairs. The teacher forms two pairs in each group to share and discuss their responses in order to arrive at a common response: (3) Share. The pairs share their answers among themselves for a few minutes, having to work out a common answer. Then the teacher calls one member from each group to SHARE the answers. This method enables a great deal of oral and written argumentation, promotes debate from different perspectives and increases the quality of responses by adding waiting time (Lyman, 1987). Students have more time to think, become more involved in discussions, thus improving the quality of their responses (Rowe, 1974). Several authors such as Carinih (2020), Cortright et al. (2005), Fauzi et al. (2021), Hunt et al. (2018), Kaddoura, (2013), and Kurjum et al, (2020) consider that this method has a great impact on the classroom, increasing critical thinking, the quality of learning and creative writing.

The Jigsaw method consists in placing students in small, heterogeneous study groups (home group), which will work on the same theme. The subject is divided into as many parts as there are elements of the group, with each student having to prepare his/her part based on the information provided by the teacher and other that he/she might collect. Then, the students from all the groups who are going to prepare/study the same part come together in subgroups to discuss and learn together. In other words, the group is divided and each member joins another group (the expert group) formed by the elements of the various groups that have been assigned the same part, exchanging information, clarifying doubts. Upon completing of the activities in the expert groups, students return to their home groups and teach their parts to each other. During the whole activity, the teacher acts as a mediator. At the end, he/she evaluates each student through, for example, direct observation of the performance of each one in the groups, or the realization of a mini-test or activity. Teams can be assigned names, given points for the results, adding the values of individual assessments, to the total group's score. Teachers often reward students in the form of positive phrases/praise, in order to encourage the performance of all members (Lopes \& Silva, 2009; Slavin, 1995).

The Jigsaw type of cooperative learning model encourages students to remember and understand the subject matter. This happens when they explain to each other the contents of the materials to the other group members. However, in order to develop 
higher-order thinking skills, it is necessary to present a problem that learners can work on and solve through analysis, evaluation, and creation of ideas (Asyari et al., 2016; Nurmalia \& Syahrun, 2020).

If the literature at the basic and secondary levels of education has been abundant in showing how CL influences cognitive development positively, it is only recently that CL has been considered in the HEI as a promising and effective pedagogical strategy to promote CCT skills and dispositions (Bezanilla et al., 2019; Johnson et al., 2006; Klimovienė et al., 2006; Silva et al., 2019)..

\section{Cooperative Learning with Concept Maps, and Creative and Critical Thinking}

$\mathrm{CM}$ constitute a research tool and an instructional technique that can be used for meaningful learning. According to Ausubel's learning theory, meaningful learning is achieved when learners can relate new knowledge to relevant concepts they already own (Novak et al., 1983; Sadler et al., 2015). A CM is a visual graphic representation of the relations between key-concepts related to the theme or content, creating meaningful structures. According to Novak and Gowin (1984) CM involves identifying the focus question and the most important concepts associated with it, and in ordering the concepts from the general (at the top) to the specific (below) in an usually hierarchical structure. The relations established between concepts through connecting words create logical propositions.

Using CM can result in an outcome towards higher order thinking skills or CCT when self and hetero regulation occurs. When students question, confirm, verify or correct their reasoning or results, it implies that they mobilize CCT skills like inferential reasoning, interpretation, analysis, evaluation, synthesis (Cañas et al., 2017). Also, the cross connections between concepts in different segments of the map predicate students' faculty of creating new knowledge (at least for the learner). This process represents frequently creative moments in which students produce knowledge, important for the facilitation of creative thinking (Novak \& Cañas, 2008).

At the Higher Education level, studies which combine CL and CM are scarce. An interesting one led by Simper et al. (2016), shows the positive effects of CM on creativity in students of an undergraduate course. The one by Bixler et al. (2015) was not conclusive as to the development of CCT, since the difference in the post CCT's test scores was not significant, although there was a clear improvement in content knowledge. The present article will thus contribute to the knowledge on the effects of CL, CM and CCT in HE.

\section{METHOD}

\section{Participants}

The participants included 55 students from three 3rd year classes of a public university in the North of Portugal. Group 1 included 22 undergraduate students in Psychology. As for gender, 90.9\% were female, aged between 19 and 22 years old $(\mathrm{M}=20.2 ; \mathrm{SD}=0.9)$. Group 2 consisted of 14 students from the Preservice Elementary Teachers degree. With regard to gender, $85.7 \%$ were female, aged between 19 and 31 years old $(\mathrm{M}=21.1$; $\mathrm{SD}$ $=3.0$ ). Group 3 consisted of 19 undergraduate students from the Pre-service Elementary 
Teachers degree. With regard to gender, $84.2 \%$ were female, aged between 20 and 37 years old $(\mathrm{M}=21.6 ; \mathrm{SD}=4.2)$. None of the students had previous experience nor in $\mathrm{CL}$ or in $\mathrm{CM}$.

\section{Materials and Measures}

The only measure used to evaluate the development of CCT came up from the application and results of a CCT test validated for the Portuguese HE population and in open access (Lopes et al., 2019). The CCT test is a paper-and-pencil test that presents a common problem situation of daily life, in which problematic circumstances can be identified and solutions have to be presented. The respondent is asked to answer a set of six open-ended questions which refer to different cognitive tasks and require their appreciation and resolution, using CCT skills, taking into consideration the Bloom's taxonomy reviewed by the references of Facione (1990) and Anderson et al. (2000) into the following CCT skills classification: (i) interpretation, (ii) analysis, (iii) explanation, (iv) evaluation, (v) synthesis and (vi) production/creation. The test total score ranges from 0 to 25 points. The inter-judge reliability of the test (Cohen kappa coefficient) ranged between 0.76 and 0.93 (Lopes et al., 2019).

\section{Procedures}

A quasi-experimental design using a convenience sample was used for this study with three non-randomized and non-equivalent groups with 3rd year undergraduate students. This study took place during one semester, in the 2018/19 academic year, which corresponded to 15 classes of 120 minutes each.

\section{Group 1: Lecture}

At the beginning of the semester, students answered the CCT test in the first class (pretest). Throughout the following 13 classes, the course contents were lectured by the teacher. The syllabus contained topics involving CCT notions. These were delivered in a theoretical way, and activities that promote CCT skills were not the primary focus. The lesson contents were supported by PowerPoints. The interaction was predominantly teacher-student, based on knowledge verification questions. Students asked questions to clarify doubts and performed individual exercises to verify their learning. At the end of the semester, in the last class, the students answered the CCT test again.

\section{Group 2: Cooperative Learning}

In the first class of the semester, the following activities were done : 1) students answered the CCT test (pre-test); 2) the teacher organized heterogeneous groups of four to five students; 3) different roles were assigned to each member of the group, on a rotating basis and adjusted to the objectives of the activities. Throughout the following 13 classes: 4) students in the cooperative groups used Think-Pair-Share (Lyman, 1987) to analyse pedagogical scenarios, which involved problem solving (classroom situations related to learning problems, indiscipline, lack of motivation) and for which students had to answer questions aimed at developing the CTT skills assessed by the test; 5) using Jigsaw (Slavin, 1995) they read and analysed articles on teaching-learningmethods on which they had to answer questions that promoted CCT skills intentionally and explicitly; 6) works were exchanged between groups for peers' feedback; 7) the 
teacher gave feedback to the works of each group after the feedback given by their colleagues; 8) students improved their work, incorporating feedback from colleagues (feedback from peers) and from the teacher; 9) each small group made a final oral presentation to the whole class; 10) each group periodically developed a reflection on the functioning of the group (group process), namely in relation to the strengths, weaknesses and possible improvement strategies. At the end of the semester, in the last class, the students answered the CCT test (post test).

\section{Group 3: Cooperative Learning and Concept Maps}

Group 3 functioned similarly to group 2 until step 4; 5) using Jigsaw (Slavin, 1995) students read and analysed articles on teaching-learning-methods on which they had to elaborate two CM, to promote CCT skills intentionally and explicitly; 6) CM were exchanged between groups for peers' feedback. Steps 7, 8, 9 and 10 are the same as the ones in group 2.

The learning activities in the CL (2 and 3) groups (without or with CM), were designed according to a preliminary CCT skills diagnosis provided by the CCT pre-test.

\section{FINDINGS}

The aim of this study was to verify if there were differences between the three groups lecture (group 1), CL only (group 2) and CL + CM (group 3) - in the development of CCT skills.

Table 1 presents the descriptive statistics of the total score of the participants in the CCT pre-test and in the CCT post-test. The gains are given by the difference between the total score in the CCT post-test and the CCT pre-test.

Table 1

Descriptives of the total score in the CCT test

\begin{tabular}{llll}
\hline & Group 1: Lecture & Group 2: CL & Group 3:CL + CM \\
\hline Pre-test & $13.7 \pm 2.95$ & $10.4 \pm 3.30$ & $11.4 \pm 2.95$ \\
\hline Post-test & $12.0 \pm 3.54$ & $14.4 \pm 2.79$ & $16.6 \pm 3.27$ \\
\hline Gains & $-1.64 \pm 4.11$ & $4.07 \pm 2.46$ & $5.16 \pm 3.44$ \\
\hline
\end{tabular}

After validating the normality of the data and the homogeneity of the variances (homoscedasticity), the results of a one-way ANOVA for the three groups of participants show that there was a statistically significant difference between groups in the CCT pre-test $(\mathrm{F}(2,52)=5.82, \mathrm{p}=.005)$, in the CCT post-test $(\mathrm{F}(2,52)=9,60, \mathrm{p}<$ $0.001)$ and in the CCT scores gains $(\mathrm{F}(2,52)=21.7, \mathrm{p}<.001)$. The Tukey post hoc test indicates that Group 1 had a significantly higher mean score in the CCT pre-test than groups 2 and 3, and that Group 1 had a significantly lower mean score in CCT post-test and in the gain in CCT tests. There are no statistically significant differences between the scores of groups 2 and 3 with CL methods. Although the groups weren't equivalent at the beginning of the semester, these results show that the students who experienced CL, have a higher increase of creative and critical thinking skills during a semester than students in a traditional learning/lecturing environment, and that the use, or not, of $\mathrm{CM}$ in CL leads to similar results in promoting CCT. 
Regarding the CCT test's scores of each group, results of a paired samples t-test reveal that the decrease of the mean score in the CCT test of students in Group 1 wasn't statistically significant $(\mathrm{t}(21)=1.87, \mathrm{p}=.076)$, whereas there was a significant increase of the mean score for Group $2(\mathrm{t}(13)=-6.18, \mathrm{p}<.001)$ and for Group $3(\mathrm{t}(18)=-6.54, \mathrm{p}$ $<.001)$

As for the analysis of the evolution of students in each dimension assessed by the CCT test, in order to test if there were significant differences between the results of each group in the pre-test and in the post-test, the Wilcoxon test was used in alternative to a paired t-test since the data didn't have a normal distribution. In Table 2, the descriptive statistics of the scores for each group of students and the results of the Wilcoxon test are presented.

Table 2

Score in the CCT test for each dimension of group $1(\mathrm{~N}=22)$

\begin{tabular}{|c|c|c|c|c|}
\hline Dimension & & Group 1 & Group 2 & Group 3 \\
\hline \multirow[t]{3}{*}{ Interpretation } & Pre-test & $1.09 \pm 1.06$ & $0.71 \pm 0.47$ & $1.26 \pm 1.05$ \\
\hline & Post-test & $1.36 \pm 1.00$ & $1.14 \pm 0.54$ & $1.74 \pm 0.73$ \\
\hline & Wilcoxon Test & $\begin{array}{l}\mathrm{Z}=-0.96 \\
\mathrm{p}=.34\end{array}$ & $\begin{array}{l}\mathrm{Z}=-1.90 \\
\mathrm{p}=.058\end{array}$ & $\begin{array}{l}\mathrm{Z}=-1.80 \\
\mathrm{p}=.073\end{array}$ \\
\hline \multirow{3}{*}{$\begin{array}{l}\text { Analysis a } \\
\text { (inference) }\end{array}$} & Pre-test & $2.05 \pm 0.38$ & $2.00 \pm 0.00$ & $2.11 \pm 0.32$ \\
\hline & Post-test & $2.23 \pm 0.43$ & $2.29 \pm 0.47$ & $2.15 \pm 0.50$ \\
\hline & Wilcoxon Test & $\begin{array}{l}\mathrm{Z}=-2.00 \\
\mathrm{p}=.046^{*}\end{array}$ & $\begin{array}{l}\mathrm{Z}=-2.00 \\
\mathrm{p}=.046^{* *}\end{array}$ & $\begin{array}{l}Z=-0.58 \\
p=.564 *\end{array}$ \\
\hline \multirow{3}{*}{$\begin{array}{l}\text { Analysis b } \\
\text { (argumentation) }\end{array}$} & Pre-test & $0.86 \pm 0.71$ & $0.93 \pm 0.48$ & $1.05 \pm 0.40$ \\
\hline & Post-test & $1.05 \pm 0.90$ & $1.07 \pm 0.62$ & $1.63 \pm 0.60$ \\
\hline & Wilcoxon Test & $\begin{array}{l}Z=-0.94 \\
p=.35\end{array}$ & $\begin{array}{l}\mathrm{Z}=-1.00 \\
\mathrm{p}=.32\end{array}$ & $\begin{array}{l}\mathrm{Z}=-2.84 \\
\mathrm{p}=.005^{*}\end{array}$ \\
\hline \multirow[t]{3}{*}{ Explanation } & Pre-test & $1.59 \pm 0.67$ & $1.57 \pm 0.76$ & $1.26 \pm 0.99$ \\
\hline & Post-test & $1.82 \pm 0.96$ & $1.64 \pm 0.74$ & $2.42 \pm 0.96$ \\
\hline & Wilcoxon Test & $\begin{array}{l}\mathrm{Z}=-0.72 \\
\mathrm{p}=.47\end{array}$ & $\begin{array}{l}Z=-0.29 \\
p=.77\end{array}$ & $\begin{array}{l}Z=-3.28 \\
p=.001 *\end{array}$ \\
\hline \multirow[t]{3}{*}{ Evaluation } & Pre-test & $1.36 \pm 0.66$ & $1.00 \pm 0.88$ & $0.68 \pm 0.48$ \\
\hline & Post-test & $0.95 \pm 0.65$ & $1.29 \pm 0.73$ & $1.42 \pm 0.69$ \\
\hline & Wilcoxon Test & $\begin{array}{l}\mathrm{Z}=-1.98 \\
\mathrm{p}=.048^{*}\end{array}$ & $\begin{array}{l}\mathrm{Z}=-1.26 \\
\mathrm{p}=.21\end{array}$ & $\begin{array}{l}\mathrm{Z}=-2.95 \\
\mathrm{p}=.003^{*}\end{array}$ \\
\hline \multirow[t]{3}{*}{ Synthesis } & Pre-test & $1.23 \pm 1.11$ & $1.14 \pm 1.35$ & $1.32 \pm 1.11$ \\
\hline & Post-test & $1.64 \pm 1.33$ & $2.36 \pm 1.15$ & $2.47 \pm 0.96$ \\
\hline & Wilcoxon Test & $\begin{array}{l}\mathrm{Z}=-1.22 \\
\mathrm{p}=.22\end{array}$ & $\begin{array}{l}\mathrm{Z}=-2.37 \\
\mathrm{p}=.018^{*}\end{array}$ & $\begin{array}{l}\mathrm{Z}=-3.00 \\
\mathrm{p}=.003^{*}\end{array}$ \\
\hline Creativity- & Pre-test & $1.45 \pm 0.67$ & $0.93 \pm 0.48$ & $1.53 \pm 0.70$ \\
\hline \multirow[t]{2}{*}{ Fluency } & Post-test & $0.82 \pm 0.50$ & $1.50 \pm 0.76$ & $1.42 \pm 0.69$ \\
\hline & Wilcoxon Test & $\begin{array}{l}\mathrm{Z}=-2.72 \\
\mathrm{p}=.006^{*}\end{array}$ & $\begin{array}{l}\mathrm{Z}=-2.53 \\
\mathrm{p}=.011 *\end{array}$ & $\begin{array}{l}Z=-0.63 \\
p=.53\end{array}$ \\
\hline Creativity- & Pre-test & $1.77 \pm 0.43$ & $0.93 \pm 0.48$ & $0.95 \pm 0.40$ \\
\hline \multirow[t]{2}{*}{ Flexibility } & Post-test & $0.77 \pm 0.43$ & $1.36 \pm 0.50$ & $1.26 \pm 0.56$ \\
\hline & Wilcoxon Test & $\begin{array}{l}\mathrm{Z}=-3.79 \\
\mathrm{p}<.001 *\end{array}$ & $\begin{array}{l}\mathrm{Z}=-2.45 \\
\mathrm{p}=.014 *\end{array}$ & $\begin{array}{l}Z=-1.73 \\
p=.083^{*}\end{array}$ \\
\hline Creativity- & Pre-test & $2.27 \pm 0.55$ & $1.14 \pm 0.86$ & $1.16 \pm 0.76$ \\
\hline \multirow[t]{2}{*}{ Originality } & Post-test & $1.55 \pm 0.91$ & $1.79 \pm 0.98$ & $1.95 \pm 0.78$ \\
\hline & Wilcoxon Test & $\begin{array}{l}\mathrm{Z}=-2.49 \\
\mathrm{p}=.013^{*}\end{array}$ & $\begin{array}{l}\mathrm{Z}=-2.25 \\
\mathrm{p}=.024 *\end{array}$ & $\begin{array}{l}Z=-2.72 \\
p=.007 *\end{array}$ \\
\hline
\end{tabular}

Group 1 had a statistically significant higher median in the CCT post-test in analysis-a, and statistically significant lower medians in the CCT post-test in the dimensions of 
creativity - fluency, creativity - flexibility, and creativity - originality. Group 2 had statistically significant higher medians in the CCT post-test in the dimensions of analysis-a, synthesis, creativity - fluency, creativity - flexibility, and creativity originality. Group 3 had statistically significant higher medians in the CCT post-test in dimensions of analysis-b, explanation, evaluation, synthesis and creativity - originality.

Comparing the gains of the three groups in each dimension evaluated by the CCT test, the results of the Kruskal-Wallis test are shown in Table 3. They allow to conclude that there are statistically significant differences between the median scores of the groups in the dimensions of explanation, evaluation and creativity (fluency, flexibility and originality). With Bonferroni correction post hoc test, there was a statistically higher gain in the dimension of explanation in Group 3 (CL and CM) than in Group 2 (CL), and creativity skills gains were generally statistically higher for groups with $\mathrm{CL}$ compared to Group 1 (Lecture).

Table 3

Results of the comparison of the gains of the three groups

\begin{tabular}{|c|c|c|}
\hline Dimension & Kruskal-Wallis Test & $\begin{array}{l}\text { Post hoc test } \\
\text { (Bonferroni correction) }\end{array}$ \\
\hline Interpretation & $\chi^{2}(2)=0.20 ; p=.90$ & \\
\hline Analysis a (inference) & $\chi^{2}(2)=2.44 ; p=.295$ & \\
\hline Analysis b (argumentation) & $\chi^{2}(2)=3.80 ; p=.150$ & \\
\hline Explanation & $\chi^{2}(2)=7.5 ; \mathrm{p}=.023 *$ & median of G3 is higher than median of G2 $(p=0.036)$ \\
\hline Evaluation & $\chi^{2}(2)=14.1 ; p=.001^{*}$ & median of G3 is higher than median of G1 $(\mathrm{p}=0.001)$ \\
\hline Synthesis & $\chi^{2}(2)=2.70 ; p=.259$ & \\
\hline Creativity-Fluency & $\chi^{2}(2)=15.4 ; \mathrm{p}<.001 *$ & median of G2 is higher than median of G1 $(\mathrm{p}<0.001)$ \\
\hline Creativity-Flexibility & $\chi^{2}(2)=29.0 ; \mathrm{p}<.001^{*}$ & $\begin{array}{l}\text { medians of } \mathrm{G} 2 \text { and } \mathrm{G} 3 \text { are higher than median of G1 } \\
(\mathrm{p}<0.001)\end{array}$ \\
\hline Creativity-Originality & $\chi^{2}(2)=17.6 ; p<.001^{*}$ & $\begin{array}{l}\text { medians of } \mathrm{G} 2 \text { and } \mathrm{G} 3 \text { are higher than median of G1 } \\
(\mathrm{p}<0.001)\end{array}$ \\
\hline
\end{tabular}

\section{DISCUSSION}

The discussion can evolve around two set of ideas regarding the differences on the efficacy of the three teaching/learning methods analyzed in this study (lecture, CL and CL+CM). First of all, considering the total CCT scores, the results of this study confirm previous findings at lower levels of education, which show almost invariably, that active learning methods generally centered in the students have superior benefits, compared to lecture, regarding students' content comprehension and higher-order thinking (Bernstein, 2018). More specifically, our results show that there are significant (considering the global score) differences between CL (with or without CM) in the development of CCT when compared with lecture, in line with the conclusions of Anderson et al. (2005), Johnson et al. (2000), Loes and Pascarella (2017), and Zhang and Chen (2020). CL groups help students discuss the content, share ideas and solve problems. When engaged in CL groups, students increase and improve their individual level of participation to the discussions. Together with the epistemic unfreezing that occurs, their contributions become intellectually more relevant and valuable (Cottell \& Millis, 1992; Fransen et al., 2013; Gillies, 2016; Morais et al., 2017). We didn't find 
significant differences between the two CL groups, due perhaps to the fact that students only elaborated two CM in Group 3 during this study.

It is important however to note that the results presented in this article are not in line with those of Goyak (2009) on pre-service teachers which revealed no higher results in CCT skills. They are also not in line with the conclusions of Massey (2003) who showed no statistically significant differences in cognitive achievement and critical thinking scores between CL and lecture. What can be said when comparing our results with the very few contradicting ones in the literature at the Higher Education level? Is the "teacher's" factor essential here? Some literature enhances the role of an expert teacher to facilitate CL groups (Gillies, 2016). Were the activities performed in the CL groups sufficiently demanding for CCT development? In the present paper, as seen in the methodology section, the activities in the CL groups were designed according to the preliminary CCT skills diagnosis. Are the differences related to the CL used techniques (Think-Pair -Share and Jigsaw)? In this article, the used CL techniques are referenced as being powerful to promote CCT skills (Azizah \& Putri, 2020; Carinih, 2020; Fauzi et al., 2021; Saputra et al., 2019; Subiyantari et al., 2019). Can the duration of the intervention influence the results as stated in much of the literature on pedagogical interventions?

Secondly, our results take us to discussion on the benefits of the inclusion of CM in CL. Although there are no statistic significant differences for the total CCT score between the $\mathrm{CL}$ group and the $\mathrm{CL}+\mathrm{CM}$ group, there are differences at the subscores of CCT skills, namely in the dimension of explanation. As other studies have shown, if concept maps are created in cooperative groups, students have to negotiate their understanding of concepts and the construction of the propositions. Not only do they have to analyze information, interpret it, evaluate it, construct meaning, but they must also argue their positions among themselves and between them and the teacher (Cañas et al., 2017). The authors of this article believe that this dynamic is beneficial for the development of the explanation skill (of one's own opinion, understanding), which can be enriched by the diversity of the concept maps production of the different groups. The authors also believe that the feedback activities can also have influenced these results. More specifically with the use of $\mathrm{CM}$, knowledge appears at a more abstract (and graphic) level, which needs more explanation. The well-structured intervention of activities and the teacher's feedback might help explaining the CCT gains observed for the CL groups (Cecchini et al. 2020). Finally, along with the results of the study led by Simper et al. (2016) which shows the positive effects of CL + CM on creativity in students of an undergraduate course compared to the students who did not use CM, our findings do not align with those of Bixler et al. (2015) which pre-tested and pos-tested medical students after 4 group concept mapping in the semester and didn't find significant difference in CCT post-test scores. In the present study, the absence of significant differences at the total scores' levels between $\mathrm{CL}$ and $\mathrm{CL}+\mathrm{CM}$ can be explained by the few concept maps (2) performed in CL groups. Some literature (Bilik et al., 2020) points out to the leverage time needed by students to appropriate themselves the CM production features and their potentiality. 


\section{CONCLUSION}

Although there are multiple studies showing the benefits of implementing CL and CM separately, fewer are the studies at the HE level and fewer still directed at comparing the impact of implementing lecture, $\mathrm{CL}$ and $\mathrm{CL}+\mathrm{CM}$. The present article had the objective to evaluate the differences of these teaching/learning methods in the development of CCT skills. The main result is that the CL (with or without $\mathrm{CM}$ ) has more impact in CCT development than lecture. Moreover, the explanation skill is more developed in the CL+CM group.

Some questions/issues can be drawn from these results. Is the inexistence of differences between the total CCT scores of the CL and CL+CM groups due to the role of the teacher, to the kind of activities that students had to perform, to the characteristics of the CL groups, or to the low number of CM performed?

Despite these questions which need to be investigated, our results allow us to recommend, in line with most of the studies, that CL brings higher benefits for CCT development compared to lecture. Therefore teachers should invest in CL methods such as Think-Pair-Share and Jigsaw. This study does not allow us to give the recommendation to teachers, that the association on $\mathrm{CL}$ and $\mathrm{CM}$ has a superior impact than the use of CL alone. A study with a larger number of students and the performance of more $\mathrm{CM}$ in CL groups must be undertaken. Further investigation should also be carried out to verify if CL has an equal impact with students from other academic areas, such as Science and Technology, Life Sciences and Environment, or Health. Other limitations of this study, such as having used a convenience sample from a single university campus with the predominance of female students, should also be minimized with a more comprehensive study that would allow to test the generalization of our results.

\section{REFERENCES}

Al-Zahrani, A. M. (2015). From passive to active: The impact of the flipped classroom through social learning platforms on higher education students' creative thinking. British Journal of Educational Technology, 46(6), 1133-1148. https://doi.org/10.1111/bjet.12353

Anderson, L., Krathwohl, D., Airasian, P., Cruikshank, K., Mayer, R., Pintrich, P., Raths, J., \& Wittrock, M. (2000). Taxonomy for Learning, Teaching, and Assessing, A: A Revision of Bloom's Taxonomy of Educational Objectives, Complete Edition (Complete ed.). Pearson.

Anderson, W. L., Mitchell, S. M., \& Osgood, M. P. (2005). Comparison of student performance in cooperative learning and traditional lecture-based biochemistry classes. Biochemistry and Molecular Biology Education, 33(6), 387-393. https://doi.org/10.1002/bmb.2005.49403306387

Asyari, M., Al Muhdhar, M. H. I., Susilo, H., \& Ibrohim. (2016). Improving critical thinking skills through the integration of problem-based learning and group investigation. International Journal for Lesson and Learning Studies, 5(1), 36-44. https://doi.org/10.1108/IJLLS-10-2014-0042 
Azizah, Z., \& Putri, L. D. (2020). The Use of Cooperative Learning Type Jigsaw in Improving Critical Thinking Skills of Student in Course Media Learning of PLS. Digital Press Social Sciences and Humanities, 6, 00015. https://doi.org/10.29037/digitalpress.46380

Bernstein, D. A. (2018). Does active learning work? A good question, but not the right one. Scholarship of Teaching and Learning in Psychology, 4(4), 290-307. https://doi.org/10.1037/st10000124

Bezanilla, M. J., Fernández-Nogueira, D., Poblete, M., \& Galindo-Domínguez, H. (2019). Methodologies for teaching-learning critical thinking in higher education: The teacher's view. Thinking Skills and Creativity, 33, 100584. https://doi.org/10.1016/j.tsc.2019.100584

Bilik, Ö., Kankaya, E. A., \& Deveci, Z. (2020). Effects of web-based concept mapping education on students' concept mapping and critical thinking skills: A double blind, randomized, controlled study, Nurse Education Today, 86, 104312. https://doi.org/10.1016/j.nedt.2019.104312

Bixler, G. M., Brown, A., Way, D., Ledford, C., \& Mahan, J. D. (2015). Collaborative Concept Mapping and Critical Thinking in Fourth-Year Medical Students. Clinical pediatrics, 54(9), 833-839. https://doi.org/10.1177/0009922815590223

Bloom, B. S., Engelhart, M. D., Furst, E. J., Hill, W. H., \& Krathwohl, D. R. (1956). Taxonomy of educational objectives, handbook I: The cognitive domain. David McKay Co Inc.

Bonk, C. J., \& Smith, G. S. (1998). Alternative instructional strategies for creative and critical thinking in the accounting curriculum. Journal of Accounting Education, 16(2), 261-293. https://doi.org/10.1016/S0748-5751(98)00012-8

Canaleta, X., Vernet, D., Vicent, L., \& Montero, J. A. (2014). Master in teacher training: A real implementation of active learning. Computers in Human Behavior, 31, 651-658. https://doi.org/10.1016/j.chb.2013.09.020

Cañas, A. J., Reiska, P., \& Möllits, A. (2017). Developing higher-order thinking skills with concept mapping: A case of pedagogic frailty. Knowledge Management and ELearning, 9(3), 348-365. https://doi.org/10.34105/j.kmel.2017.09.021

Carinih, C. (2020). Efforts to improve student critical thinking skills in IPS learning through think pair share type discussion method. Jurnal Pajar (Pendidikan Dan Pengajaran), 4(2), 1-20. https://doi.org/10.33578/pjr.v4i2.7961

Cecchini, J.A., Fernandez-Rio, J., Mendez-Gimenez, A., Gonzalez, C., SanchezMartínez, B., \& Carriedo, A. (2020). High versus low-structured cooperative learning. Effects on prospective teachers' regulation dominance, motivation, content knowledge and responsibility. European Journal of Teacher Education, 1-16. https://doi.org/10.1080/02619768.2020.1774548

Cortright, R. N., Collins, H. L., \& DiCarlo, S. E. (2005). Peer instruction enhanced meaningful learning: Ability to solve novel problems. Advances in Physiology Education, 29(2), 107- 111. 
Cottell, P., \& Millis, B. (1992). Cooperative learning in accounting. Journal of Accounting Education, 10(1), 95-111. https://doi.org/10.1016/0748-5751(92)90019-2 .

Council of Europe (2016). Competences for Democratic Culture - Living together as equals in culturally diverse democratic societies. https://go.coe.int/yJqEd

Dominguez, C. (coord.) (2018). A European review on Critical Thinking educational practices in Higher Education Institutions. UTAD, Portugal.

Facione, P. A. (1990). Critical thinking: A statement of expert consensus for purpose of educational assessment and instruction'. Executive summary, The Delphi Report. California Academic Press. https://www.qcc.cuny.edu/socialsciences/ppecorino/CTExpert-Report.pdf

Fauzi, F., Erna, M., \& Linda, R. (2021). The Effectiveness of Collaborative Learning Through techniques on Group Investigation and Think Pair Share Students' Critical Thinking Ability on Chemical Equilibrium Material. Journal of Educational Sciences, 5(1), 198. https://doi.org/10.31258/jes.5.1.p.198-208

Fransen, J., Weinberger, A., \& Kirschner, P. A. (2013). Team effectiveness and team development in CSCL. Educational Psychologist, 48(1), 9-24. https://doi.org/10.1080/00461520.2012.747947

Fullan, M., Quinn, J., \& McEachen, J. (2018). Deep learning. Engage the World Change the World. Corwin/Principals' Council.

Gillies, R. M. (2016). Cooperative Learning: Review of Research and Practice. Australian Journal of Teacher Education, 4l(3). http://dx.doi.org/10.14221/ajte.2016v41n3.3

Goyak, A. M. (2009). The effects of cooperative learning techniques on perceived classroom environment and critical thinking skills of preservice teachers (Doctoral dissertation), Liberty University. http://digitalcommons.liberty.edu/doctoral/147

Halpern, D. F., \& Dunn, D. S. (2021). Thought and Knowledge: An Introduction to Critical Thinking (6th ed.). Routledge.

Hämäläinen, R., \& Vähäsantanen, K. (2011). Theoretical and pedagogical perspectives on orchestrating creativity and collaborative learning. Educational Research Review, 6(3), 169-184. https://doi.org/10.1016/j.edurev.2011.08.001

Hunt, J. H., MacDonald, B., Lambert, R., Sugita, T., \& Silva, J. (2018). Think-PairShow-Share to Increase Classroom Discourse. Teaching Children Mathematics, 25(2), 78-84. https://doi.org/10.5951/teacchilmath.25.2.0078

Johnson, D. W., \& Johnson, R. T. (2014). Cooperative Learning in 21st Century. [Aprendizaje cooperativo en el siglo XXI]. Anales de Psicología, 30(3), 841-851. https://doi.org/10.6018/analesps.30.3.201241

Johnson, D. W., Johnson, R.T., \& Stane, M. E. (2000). Cooperative learning methods: a meta-analysis. 
https://www.researchgate.net/publication/220040324_Cooperative_learning_methods_A _meta-analysis

Johnson, D. W., Johnson, R. T., \& Smith, K. A. (2006). Active Learning: Cooperation in the College Classroom. Interaction Book Co.Kaddoura, M. (2013). Think Pair Share: A Teaching Learning Strategy to Enhance Students' Critical Thinking. Journal of Educational Research $\quad$ Quarterly. $36(4), \quad 34$. https://files.eric.ed.gov/fulltext/EJ1061947.pdf

Kaufman, J. C., \& Sternberg, R. J. (2019). The Cambridge Handbook of Creativity (Cambridge Handbooks in Psychology) (2nd ed.). Cambridge University Press.

Klimovienè, G., Urbonienè, J., \& Barzdžiukienè, R (2006). Developing critical thinking through cooperative learning. Studies About Languages, 9, 77-85. https://www.kalbos.1t/zurnalai/09_numeris/11a.pdf

Kurjum, M., Muhid, A., \& Thohir, M. (2020). Think-pair-share model as solution to develop students' critical thinking in islamic studies: Is it effective? Cakrawala Pendidikan, 39(1), 144-155. https://doi.org/10.21831/cp.v39i1.28762

Kusumoto, Y. (2018). Enhancing critical thinking through active learning. Language Learning in Higher Education, 8(1), 45-63. https://doi.org/10.1515/cercles-2018-0003

Loes, C. N., \& Pascarella, E. T. (2017). Collaborative Learning and Critical Thinking: Testing the Link. The Journal of Higher Education, 88(5), 726-753. https://doi.org/10.1080/00221546.2017.1291257

Lopes, J., Silva, H. (2009). A Aprendizagem Cooperativa na Sala de Aula. Um guia prático para o professor [The cooperative learning in the classroom. A practical guide for the teachers]. Lidel, Edições Técnicas, Lda.

Lopes, J., Silva, H., \& Morais, E. (2019). Teste do Pensamento Crítico e Criativo para estudantes do ensino superior [Critical and Creative Thinking Test for Higher Education Students]. Revista Lusófona de Educação, 44(44), 173-189. https://doi.org/10.24140/issn.1645-7250.rle44.11

Lucas, B., \& Spencer, E. (2017). Teaching Creative Thinking: Developing learners who generate ideas and can think critically (Pedagogy for a Changing World series). Crown House Publishing Ltd.

Lyman, F (1987). Think-Pair-Share: An Ending Teaching Technique. MAA-CIE Cooperative News, 1(1), 1-2. https://serc.carleton.edu/introgeo/interactive/tpshare.html

Massey, S. (2003). The Effects of Cooperative Learning Versus Traditional Classroom Instruction on Cognitive Achievement, Critical Thinking, and Attitudes Toward Learning in Teams in a Physician Assistant Program (Doctoral Dissertation). https://digitalcommons.andrews.edu/dissertations/562

McKeachie, W., \& Svinicki, M. (2014). Teaching Tips: Strategies, Research, and Theory for College and University Teachers (14th ed.). Cengage Learning. 
Morais, T., Silva, H., Lopes, J., \& Dominguez, C. (2017). Argumentative skills development in teaching philosophy to secondary school students through constructive controversy: an exploratory study case. The Curriculum Journal, 28(2), 249-265. https://doi.org/10.1080/09585176.2016.1267654

Norris, S. P., \& Ennis, R. H. (1989). Evaluating Critical Thinking (Practitioner Guide to Teaching Thinking Series) (1st ed.). Midwest Publications.

Novak, J. D., \& Cañas, A. J. (2008). The theory underlying concept maps and how to construct them. Technical Report IHMC CmapTools 2006-01 Rev 01-2008. Florida Institute for Human and Machine Cognition

Novak, J. D., \& Gowin, D. B. (1984). Learning how to learn. Cambridge University Press

Novak, J. D., Gowin, D. B., \& Johansen, G. T. (1983). The Use of Concept Mapping and Knowledge Vee Mapping with Junior High School Science Students. Science Education, 67(5), 625-645. https://doi.org/10.1002/sce.3730670511

Nurmalia, A., \& Syahrun, N. (2020). Application of jigsaw type cooperative learning to improve student creative thinking skills. IOP Conf. Series: Journal of Physics: Conf. Series 1460 (2020) 012142 IOP Publishing https://doi.org/10.1088/1742$6596 / 1460 / 1 / 012142$

OECD (2018). Future of education and skills. Education 2030 http://www.oecd.org/education/2030-project/

Paul, R., \& Elder, L. (2019). The nature and functions of critical \& creative thinking. Rowman \& Littlefield.

Rowe, M. B. (1974). Relation of wait-time and rewards to the development of language, logic, and fate control: Part II-Rewards. Journal of Research in Science Teaching, 11(4), 291-308. https://doi.org/10.1002/tea.3660110403

Sadler, K., Stevens, S., \& Willingham, J. (2015). Collaborative Concept Maps: A Voice for All Science Learners. Science Scope, O38(9). https://doi.org/10.2505/4/ss15_038_09_38

Saputra, M. D., Joyoatmojo, S., Wardani, D. K., \& Sangka, K. B. (2019). Developing Critical-Thinking Skills through the Collaboration of Jigsaw Model with Problem-Based Learning Model. International Journal of Instruction, 12(1), 1077-1094. https://doi.org/10.29333/iji.2019.12169a

Schmidt, H. G., Wagener, S. L., Smeets, G. A., Keemink, L. M., \& van der Molen, H. T. (2015). On the Use and Misuse of Lectures in Higher Education. Health Professions Education, 1(1), 12-18. https://doi.org/10.1016/j.hpe.2015.11.010

Schroeder, N. L., Nesbit, J. C., Anguiano, C. J., \& Adesope, O. O. (2017). Studying and Constructing Concept Maps: a Meta-Analysis. Educational Psychology Review, 30(2), 431-455. https://doi.org/10.1007/s10648-017-9403-9 
Silva, H., Lopes, J., \& Dominguez, C (2019). Enhancing College Students' Critical Thinking Skills in Cooperative Groups. In Tsitouridou M., A. Diniz J., Mikropoulos T. (eds) Technology and Innovation in Learning, Teaching and Education. TECH-EDU 2018. Communications in Computer and Information Science, vol 993. Springer, Cham.

Silva, H., Lopes, J., \& Dominguez, C. (2020). A aprendizagem cooperativa e os mapas de conceitos na promoção do pensamento crítico e criativo: uma experiência no ensino superior. [Cooperative learning and concept maps in the promotion of critical and creative thinking: an experience in higher education]. Revista Lusófona de Educação, 45, 157-170. https://doi.org/10.24140/issn.1645-7250.rle45.11

Simper, N., Reeve, R., \& Kirby, J. (2016) Effects of Concept Mapping on Creativity in Photo Stories. Creativity Research Journal, 28(1), 46-51. https://doi.org/10.1080/10400419.2016.1125263

Slavin, R. E. (1995). Cooperative learning: Theory, research, and practice (2nd Ed.). Allyn \& Bacon.

Spence, L. (2004). The Usual Doesn't Work: Why We Need Problem-Based Learning. Portal: Libraries and the Academy, 4(4), 485-493. https://doi.org/10.1353/pla.2004.0072

Sternberg, R. J. (1986). Critical thinking: Its nature, measurement, and improvement National. https://files.eric.ed.gov/fulltext/ED272882.pdf

Subiyantari, A. R., Muslim, S., \& Rahmadyanti, E. (2019). Effectiveness of Jigsaw Cooperative Learning Models In Lessons of the Basics of Building Construction on Students Learning 'Outcomes Viewed From Critical Thinking Skills. International Journal for Educational and Vocational Studies, 1(7). https://doi.org/10.29103/ijevs.v1i7.1653

Sudarmika, P., Santyasa, I. W., \& Divayana, D. G. H. (2020). Comparison between Group Discussion Flipped Classroom and Lecture on Student Achievement and Student Characters. International Journal of Instruction, 13(3), 171-186. https://doi.org/10.29333/iji.2020.13312a

Torrance, E. P. (1970). Encouraging creativity in the classroom. WC Brown Co.

UNESCO (2016). Educación para la ciudadanía mundial. Preparar a los educandos para los retos del siglo xxi. París: Organización de las Naciones Unidas para la Educación, la Ciencia y la Cultura.

Vygotsky, L. (1978). Mind and society. Harvard University Press.

Warsah, I., Morganna, R., Uyun, M., Hamengkubuwono., \& Afandi, M. (2021). The Impact of Collaborative Learning on Learners' Critical Thinking Skills. International Journal of Instruction, 14(2), 443-460. https://doi.org/10.29333/iji.2021.14225a

Zhang, J., \& Chen, B. (2020). The effect of cooperative learning on critical thinking of nursing students in clinical practicum: A quasi-experimental study. Journal of Professional Nursing, 4(11), 1-7. https://doi.org/10.1016/j.profnurs.2020.05.008 